\title{
THE ROLE OF THE GOVERNMENT, PRIVATE SECTOR AND SOCIAL CAPITAL TOWARDS DEVELOPMENT OF COMMUNITY-BASED TOURISM SUSTAINABILITY IN KUPANG NUSA TENGGARA TIMUR
}

\author{
Ringa Maria Bernadetha*, Setiawina Nyoman Djinar, Dewi Made Heny Urmila, \\ Marhaeni A.A.I.N. \\ Faculty of Economics and Business, University of Udayana, Bali, Indonesia \\ *E-mail: mariabernadetha06179@gmail.com
}

\begin{abstract}
The purpose of this study was to find out (1) the role of government, the role of the private sector and social capital on community participation in the city of Kupang; (2) the role of government private sector and social capital and community participation in sustainable tourism development in the city of Kupang; (3) the role of community participation in meditating on the role of government, private sector, and social capital, on sustainable tourism development; (4) designing the right strategy in the development ofsustainable tourism in the city of Kupang. This research was carried out in the city of Kupang, East Nusa Tenggara Province, in six subdistricts which have tourism, marine tourism, religious tourism, and artificial tourism. The sample in this study was 270 respondents. Data collectedby questionnaires were then analyzed using SEM-PLS, and to strengthen tourism strategies in Kupang city, SWOT analysis was used. The results of the research and data analysis show that: (1) the role of government, the role of the private sector, and social capital directly have a positive and significant effect on public participation; (2) the role of the private sector does not have a significant effect on sustainable tourism development; (3) community participation was able to play a part in mediating partially the role of the government, the role of the private sector and social capital towards sustainable tourism development in the city of Kupang in East Nusa Tenggara.
\end{abstract}

\section{KEY WORDS}

Government, private sector, social capital, community participation, tourism development.

For more than 60 years tourism has undergone expansion and diversification into one of the business sectors that is growing very rapidly. One of the provinces that is of central concern to the development of tourism is the Province of East Nusa Tenggara (NTT). NTT Province is one of the archipelago provinces in Indonesia whose territory is united by the Savu Sea and the Sumba Strait, with a total of 1,192 islands (large and small islands), which have natural and cultural richness that are potential enough to be developed into potential tourism destinations that are spread almost on all islands in NTT. Concrete steps undertaken by the government are the construction of facilities and infrastructure in the form of adequate infrastructure and industrial centers in tourism destinations. The involvement of community participation in the development and processing of tourism is an important factor, because the community understands and controls the region (Elfianita, 2011). Community participation is a necessity in every sustainable development as stated by Gunn (1999), which confirms that "Local people participation is prerequisite for sustainable tourism".

According to Pitana (2004), empowerment is actually an effort or process to improve the ability of local communities, so that they are able to identify existing problems in their area, discover existing potentials, analyze various strengths, weaknesses, opportunities and threats, to further be able to plan various programs in their area. Tourist arrivals to the city of Kupang have increased from 2014-2018, except in 2017 the number of tourist arrivals dropped to 9,042, due to the lack of promotion carried out by the Kupang City Tourism Office, and tourists more interested in visiting other cities in NTT such as Labuan Bajo, Ende, Sumba Island, and Alor are higher than visiting tourist destinations in Kupang City (Jelamu, 2018). In the end of 2018, the number of tourist arrivals increased to 30,657 which has an 
impact on increasing the income of local people around tourist destinations and employment in the tourism businesses. In the end of 2018, the number of tourist arrivals increased to 30,657 which has an impact on increasing the income of local people around tourist destinations and employment in the tourism businesses.

The community is empowered by utilizing local knowledge and wisdom to become subjects in development, to be independent, to be able to help themselves, and to develop a spirit of self-confidence in the local community (Kurniawati, 2007). Cooperation between the government and the private sector is very influential in community-based sustainable tourism development. Community-based tourism (Community Based Tourism (CBT) must intersect with three pillars, namely: Government, private, and community.

Community participation is the most important component in efforts to grow independence and the empowerment process (Nasikum, 1997). The government must involve the private sector in the implementation of policies, the contribution of experts, skilled workers, and donations of funds, tools and technology, while the public is involved in the form of non-mobilization participation to obtain the desired development outcomes (Sugiarti and Argy, 2009). Cooperation between the government, the public and the private sector, will support the success of community-based sustainable tourism development in the City of Kupang NTT (Bandaso, 2018).

The poverty rate in Kupang City tends to decrease in 2014-2018. Some basic problems that cause unemployment in Kupang City are limited employment, and low levels of education (BPS Kota Kupang, 2018). Concrete steps taken are community-based sustainable tourism development, and utilizing a variety of tourism destinations that have not yet been managed, in order to create jobs for the community around the tourist destinations (Maromon, 2017). With a partnership between the government, the private sector and the community in the development and processing of tourist destinations, it can reduce the unemployment rate in Kupang City, because the development of the tourism sector can absorb labor for the community (Kleden, 2018). The role of the private sector is not optimal without being supported by a strategic step taken by the management of a tourist attraction, or those who have the authority of tourism development (Zulkifly, 2013).

Sustainable tourism development in the city of Kupang, must strengthen social capital within the community, so that tourism development does not change and shift the culture and norms prevailing in society, namely by paying attention to elements in social capital, in the form of networks, beliefs, norms ( Mawarni, 2007). Social capital is very important in the development of community-based tourism, because with social capital, the community can maintain the norms and customs that apply in its area, so that tourism development can be sustainable, and can pass down cultural values to future generations.

Community-based sustainable tourism development must maintain the norms, culture and customs of an area. Social capital in the form of culture and customs can be packaged into a unique tourist attraction, which is an attraction for tourists visiting the city of Kupang (Maramon, 2017). Based on the results of the research and Focus Group Disccusion (FGD) conducted by researchers, the relationship between the government, the community and the private sector in tourist destinations, has not yet been fully realized, because there has not been a synchronization of cooperation programs in tourism development (Timex, 2018). Cooperative relationship between the government, the community and the private sector is a strong capital in the development of sustainable tourism in the city of Kupang. Community participation in the development of sustainable tourism, is often hampered due to several factors including (1) natural factors, (2) cultural factors and (3) low access development factors (Suwinda, et al., 2012., Suardana \& Dewi, 2015) . The strategy used is to use SWOT analysis. The development of tourism to the city of Kupang, requires handling and managing attractions, facilities, accessibility, infrastructure and good hospitality (Wardana, 2017). The development strategy will be an initial recommendation for the direction of tourism development in the future. With the concept of development and the right strategy, the benefits of tourism activities increasingly felt by the community and the region (Sudiarkajaya, 2018).

Based on the conceptual framework, the research hypothesis is formulated as follows: 
- The role of government, the role of the private sector and social capital has a positive effect on community participation in Kupang City, East Nusa Tenggara;

- The role of government, the role of the private sector, social capital and community participation have a positive effect on sustainable tourism development in Kupang City, East Nusa Tenggara;

- Community participation mediates the role of government, the role of the private sector, and social capital in the development of sustainable tourism in Kupang City, East Nusa Tenggara.

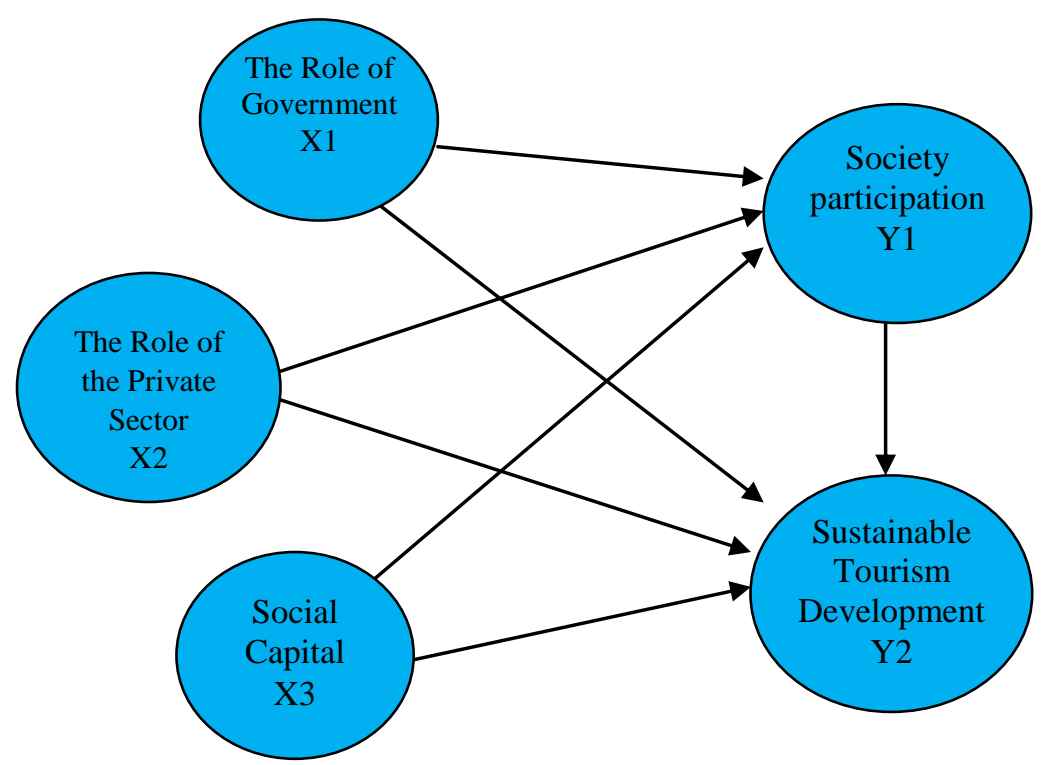

Figure 1 - Research Framework

\section{METHODS OF RESEARCH}

This research uses a quantitative approach. Interviews are conducted using the directional discussion method, where with this method the information or data obtained can be obtained with a shorter time. The research location is in Kupang City, East Nusa Tenggara Province, which administratively consists of 6 districts namely Alak District, Maulafa District, Oebobo District, Kota Raja District, Kelapa Lima District, and Kota Lama District, and consists of 51 (fifty) one) kelurahan. The population in this study was 378,425 households in six sub-districts in Kupang City, NTT. The sampling technique used in this study is Stratified Random Sampling because the population members used are not homogeneous taken based on age, occupation and education level. The sample size using a table to determine the number of samples at $1 \%, 5 \%$ and $10 \%$ error levels developed from Isaac and Michel (Sugiyono: 2002) about determining the number of population $(\mathrm{N})=$ 378,435 with an error rate of 10 percent obtained 269.97 or equal to 270 respondents The method of data collection is to use accidental sampling techniques (Margom, 2004).

Analysis of the data used in this research is quantitative analysis. Quantitative analysis is used to answer the problem using Partial Least Square (PLS) analysis. PLS as an alternative to Structural Equation Modeling with a weak theoretical basis can be used as a confirmation of the theory (Wold, 1966). PLS is a method that uses SEM (Structural Equation Modeling) model that is used to overcome the problem of relationships between complex variables but the sample size is small. The SEM method has a minimum data sample size of 100 (Hair et al., 2010).

\section{RESULTS AND DISCUSSION}

Characteristics of respondents based on age, namely most respondents have an age level between $40-49$ years which is $29.63 \%$ and the least respondents are aged less than 20 years as many as $3.33 \%$ and respondents aged over 60 years, namely $3.33 \%$. 
Most respondents have a high school education (SMU) or equivalent at as much as 50 percent. Respondents with a Postgraduate education background were the least, at only 1.11 percent. Most respondents are traders as many as 35 percent. Many respondents work as traders because, most local people around tourist destinations, use tourism objects to increase income, by marketing products that will be sold to tourists. Many respondents also work as fishermen, amounting to 10.41 percent. A fisherman is a respondent who lives in the vicinity of marine tourism destinations, where respondents use tourist destinations for tourists to use, such as fishing and snocling, surfing and other marine tourism. The smallest respondents were those from PHRI, TNI, ASITA, and cafe businesses, which were 0.37 percent.

The inner model describes the relationship between latent variables based on substantive theory. In assessing a model with PLS, it starts by looking at R-squares for each latent dependent variable. The results of testing the inner model can see the relationship between constructs by comparing the significance and R-square values of the research model (Ghozali, 2008: 42).

Table 1 - R-Squares Value

\begin{tabular}{cc}
\hline Endogenous Variables & R Square \\
\hline Society participation & 0,467 \\
Sustainable Tourism Development & 0,469 \\
\hline
\end{tabular}

Source: Data Processed, 2019.

The R-square value of the community participation variable of 0.467 in Table 1 shows that 46.7 percent of the community participation variable is explained by the variables of government roles, private roles, and social capital, while $53.3 \%$ is explained by variables outside the model. Likewise, the variable of sustainable tourism development with an $R$ Square value of 0.469 means that 46.9 percent of the variability is explained by the variables of government roles, private roles, social capital, and community participation, while 53.1 percent is explained by variables outside the model. The value of R-squre as shown in Table 1 is 0.467 and 0.469 , which means moderate.

Q2 value of structural model testing is done by looking at the value of Q2 (predictive relevance). To calculate $\mathrm{Q} 2$ the formula can be used:

$$
Q^{2}=1-\left(1-R_{1}{ }^{2}\right)\left(1-R_{2}^{2}\right)=0,717
$$

The results of the Q2 calculation show that the Q2 value is 0.717 . According to Ghozali (2014), the Q2 value can be used to measure how well the observational value generated by the model and its parameter estimates. A Q2 value> 0 (zero) indicates that the model is said to be good enough, while a Q2 value $<0$ (zero) indicates that the model lacks predictive relevance value. In this research model endogenous constructs or latent variables have a value of Q2> 0 (zero) so the predictions made by the model are considered to be relevant.

Hypothesis testing on the influence of government role variables, private roles, social capital on community participation and sustainable tourism development is presented in Figure 2.

Path coefficient values and statistical $t$ values and $p$ values for hypothesis testing are presented in Table 2.

Testing of hypotheses in the PLS method is carried out by using a simulation of each hypothesized relationship, in this case a bootstrap method is performed on the sample. The bootstrap method also serves to minimize the problem of abnormal research data used. In this study, the T-table value with a significance of $5 \%$ has been determined before, amounting to 1.96. All path coefficients in Table 5.22 have a statistical t value above 1.96 except the effect of the role of the private sector on sustainable tourism development with a static $t$ of 0.282 .

In addition to taking data by questionnaire in order to obtain accurate data at the research location, a SWOT analysis was also carried out, in order to analyze the strengths, 
weaknesses, threats and opportunities for sustainable tourism development in the city of Kupang, which is illustrated in Table 3.

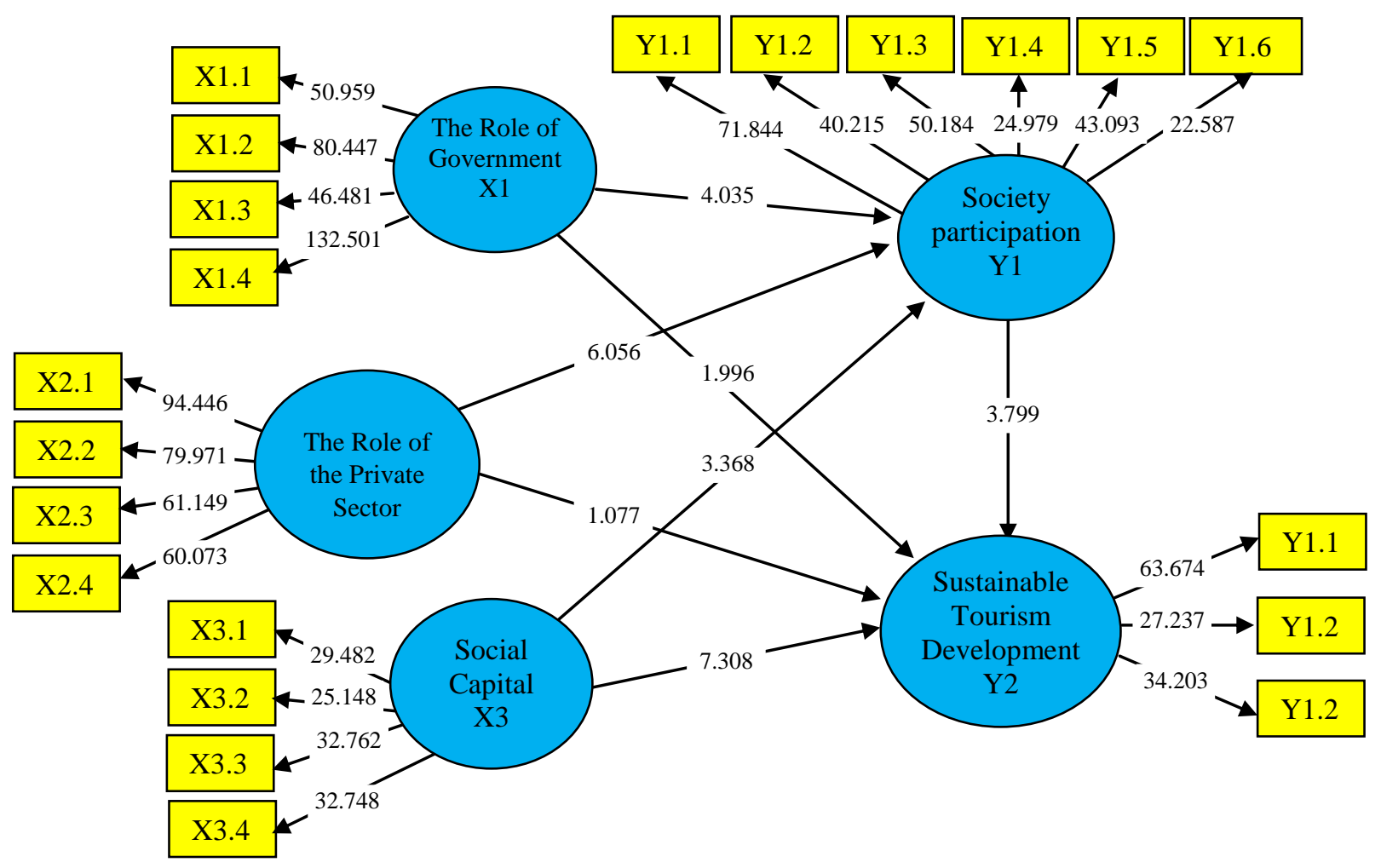

Figure 2 - Value of t Statistical Path Analysis Model (Source: Data processed, 2019)

Table 2 - Result for Inner Loadings

\begin{tabular}{|c|c|c|c|c|c|}
\hline $\mathrm{n} / \mathrm{n}$ & $\begin{array}{c}\text { Original } \\
\text { Sample (O) }\end{array}$ & $\begin{array}{c}\text { Sample } \\
\text { Mean (M) }\end{array}$ & $\begin{array}{c}\text { Standard Deviation } \\
(\text { STDEV) }\end{array}$ & $\begin{array}{c}\text { T Statistics } \\
(\mid \mathrm{O} / \text { STDEV } \mid)\end{array}$ & $\begin{array}{c}\mathrm{P} \\
\text { Values }\end{array}$ \\
\hline $\begin{array}{c}\text { The Role of Government -> Community } \\
\text { Participation }\end{array}$ & 0,281 & 0,278 & 0,070 & 4,036 & 0,000 \\
\hline Private Role -> Community Participation & 0,390 & 0,389 & 0,064 & 6,056 & 0,000 \\
\hline $\begin{array}{c}\text { Social capital -> Community } \\
\text { Participation }\end{array}$ & 0,155 & 0,160 & 0,046 & 3,368 & 0,001 \\
\hline $\begin{array}{c}\text { The Role of Government -> Pemb. } \\
\text { Sustainable Tourism }\end{array}$ & 0,131 & 0,130 & 0,066 & 1,996 & 0,047 \\
\hline $\begin{array}{c}\text { Private Role -> Pemb. Sustainable } \\
\text { Tourism }\end{array}$ & 0,076 & 0,075 & 0,071 & 1,077 & 0,282 \\
\hline $\begin{array}{c}\text { Social capital -> Pemb. Sustainable } \\
\text { Tourism }\end{array}$ & 0,389 & 0,391 & 0,053 & 7,308 & 0,000 \\
\hline
\end{tabular}

Source: Data Processed, 2019.

The positive and significant role of government in community-based tourism development is dominantly reflected by motivational indicators, namely providing tourismaware groups, bridging public and private interests, and bridging community needs with related agencies. The presence of the government can be said to encourage the acceleration of the realization of community-based tourism development in the city of Kupang. The role of the Kupang City government in encouraging community participation in destinations is still low. Community-based tourism development in the city of Kupang, must be more optimized by the government, so that it has an impact on increasing people's income in tourist destinations (Jelamu, 2017).

Suasapa (2016) revealed that, the implementation of the concept of community-based tourism in Kedonganan Beach, shows that local government support is one of the supporting factors in the implementation of community-based tourism. The meaningful role of government in the development of community-based tourism is determined by various 
factors. The results showed that the factors that led to the government's role in communitybased tourism development were positive and significant, namely trust, certainty, budget politics, guarantees. CBT is an alternative form of tourism developed by directly involving people in tourist destinations (Saarinen, 2006). The concept of community-based tourism development is a response to the various negative impacts of the development of the tourism sector that was developed in a mass manner as has developed in the last decade. According to Andereck et al, (2005) these negative impacts are particularly felt by local residents. CBT aims to involve local residents in the development of tourism in a small scale, which is part of poverty alleviation (Ernawaty, 2018). CBT has been recognized as a catalyst for socioeconomic development (Hall and Jenkins, 1998). Many countries adopt CBT in the development of the tourism sector, especially in developing countries (Davis \& Morais, 2004).

Table 3 - SWOT Analysis of the Role of Government, Private Role, Social Capital towards Community-Based Sustainable Tourism Development

\begin{tabular}{|c|c|}
\hline \multicolumn{2}{|c|}{ INTERNAL ENVIRONMENT } \\
\hline Strength-S & Weaknesses-W \\
\hline $\begin{array}{l}\text { Social capital, rules, norms, are still maintained in society; } \\
\text { Local people, can work together with the private sector, } \\
\text { and government in tourism development; } \\
\text { Tourism can create jobs for the community; } \\
\text { An increase in the quality of life of the community around } \\
\text { tourist destinations; } \\
\text { There are various customs, tribes, culture in the } \\
\text { community, which is the power in packaging tourism, in } \\
\text { Kupang City becoming cultural tourism; } \\
\text { There are many tourism destinations that can be } \\
\text { developed, so as to create jobs for the community. }\end{array}$ & $\begin{array}{l}\text { Low public understanding of the importance of } \\
\text { tourism; } \\
\text { Customary leaders or community leaders have not } \\
\text { optimally facilitated community development of } \\
\text { tourism potential; } \\
\text { Low community creativity; } \\
\text { Norms and Values adopted by the community, will } \\
\text { shift with the entry of foreign cultures, which have } \\
\text { an impact on people's lifestyles; } \\
\text { Not yet optimal strengthening of local organizations } \\
\text { in the field of tourism in the community; } \\
\text { The low participation of the community in the } \\
\text { development of sustainable tourism. }\end{array}$ \\
\hline \multicolumn{2}{|c|}{ EXTERNAL ENVIRONMENT } \\
\hline Opportunuties- $\mathrm{O}$ & Threats-T \\
\hline $\begin{array}{l}\text { The availability of accessibility by investors / private sector } \\
\text { by developing tourism facilities such as hotels, restaurants, } \\
\text { malls, and other supporting facilities; } \\
\text { Investors or the private sector, responding to the needs of } \\
\text { the community and tourists by providing accessibility; } \\
\text { Good political stability in the city of Kupang, thereby } \\
\text { attracting private interest to invest in various business } \\
\text { fields; } \\
\text { Kupang City is the capital of Prov. NTT; } \\
\text { Is the entrance of various regions that will visit various } \\
\text { cities in NTT; } \\
\text { International airport and sea port have been stranded to } \\
\text { various regions. }\end{array}$ & $\begin{array}{l}\text { The lack of private contribution in helping the } \\
\text { community and government in promoting tourism; } \\
\text { The unequal construction of facilities and } \\
\text { infrastructure in several tourist destinations; } \\
\text { There is confusion damage due to tourism } \\
\text { development; } \\
\text { The role of the government and the private sector } \\
\text { is still low in providing guidance to the community's } \\
\text { human resources around the tourist destinations; } \\
\text { There is no synergy between the bureaucracy and } \\
\text { the private sector, in the development of } \\
\text { sustainable tourism in Kupang City. }\end{array}$ \\
\hline
\end{tabular}

The role of the private sector can encourage community participation in tourism development. This is intended in the analysis of research data which shows that the private sector has a positive influence on community participation in the city of Kupang, which shows that, the better the role of the private sector, it will increase public participation. The role of the private sector on community participation in the city of Kupang, is still far from the expectations of the community, because the private sector that conducts tourism businesses in the city of Kupang, has not contributed significantly through the recruitment of local workers, or in the provision of CSA, to the local community, around the company. Cooperation between the private sector and the community is carried out with various tourism activities such as holding tourist attractions and exhibitions in the small and micro business sector (UKM), which aim to support the tourism industry. The private sector must collaborate more intensively with the community in the tourist destination, in developing human resources, in order to develop and manage tourism objects, so that the community can be involved in the process of tourism activities (Samsudin, 2005). 
Building partnerships with all tourism businesses and fostering mutually beneficial cooperation in tourism development, is inseparable from the responsibility of the tourism industry players, namely the private sector. The partnership strategy with the private sector in providing infrastructure and public services is beneficial in the development of sustainable tourism in the city of Kupang, NTT (Wardana, 2017). According to Latu (2017), building human resources in tourism is an important asset in the development of development in the city of Kupang. The development of human resources in tourist destinations is the potential contained in humans to realize their role as adaptive and transformative social beings. The role of the private sector is to increase community participation around tourist destinations by counseling, skills training, and strengthening tourism institutions through a national independent community empowerment program (PNPM) in tourist destinations (Wardana, 2017).

Social capital is cumulative and increases by itself (Putnam, 1993). Therefore, social capital will not be used up if used, but can increase. Reduced social capital due to social capital is not used (Rasmen, 2017). In line with the above concept based on the results of research and data analysis, it shows that social capital has indicators of trust, networks, and norms, a positive and significant effect on community participation in Kupang City, East Nusa Tenggara. The results of this study are in line with research conducted by Hasbulah (2006) which says that social capital is an investment in order to obtain new resources. According to Fakuyama (2005) states that by relying on the norms and shared values of associations between people will produce trust that ultimately has a large and measurable economic value. Putnam (1993) gives a statement that reinforces that good social capital will give birth to a harmonious community life.

The results showed that the factors that caused social capital in the development of community participation had a positive and significant effect, namely trust, networks, and norms. Social capital was the network dimension, trust and norms had an effect on creating employment (Jambika, 2011). The role of social capital in community participation in relation to job search and job opportunities has not been realized optimally (Indraputra, 2017). Social Capital is also associated with values such as tolerance, solidarity, or trust. (Siegler, 2014; Westlund, 2006; Lin, 2001 Michaelides et al, 2013). Four main features as indicators of social capital are the relationship of trust in general rules and norms and openness in community networks and local groups (Pretty and Ward 2001 Pretty 2003; Perreault 2003; Berggren and Jordahl 2006; Coleman 1988; Grootaert and Narayan 2004; Woolcock and Narayan 2000 ; Dasgupta).

The results of the study show that social capital influences community participation in the city of Kupang. With the existence of social capital can regulate life between communities, in accordance with applicable norms. The combination of knowledge (human capital) and cooperation (social capital) has a significant influence on economic growth, socio-culture and the environment around tourist destinations. Social capital is very much needed in the development of community-based tourism, given that the City of Kupang is unique to other regions in Indonesia because it is inhabited by various tribes in NTT whose languages, customs, culture and customs are different. It can be developed into cultural tourism, and can increase Local Revenue (PAD).

The role of government is as a motivator, initiator, authorizer, and dynamic. Based on the results of the analysis shows that the role of government has a positive and significant effect on the development of sustainable tourism. The role of the government is very dominant in the realization of sustainable tourism in the city of Kupang. Sustainable tourism development is development that pays attention to the sustainability of the ecosystem, maintaining uniqueness, local wisdom, the community as objects and subjects of development.

North (1990) states that developing the competitiveness of the business world requires government institutions in creating frame work that enables productive assets to develop to gain increasingly competitive market share and a government consideration so that existing resources can be utilized in the future for economic purposes, social and cultural that can be 
made into an attraction to maintain the integrity of cultural diversity that supports life systems (Yoeti, 2008).

Based on Article 10 of 2009 Law states that the government provides the widest opportunity for the public to participate in the organization of tourism. Furthermore, in article 14 , tourism development is directed at realizing and maintaining the preservation and integrity of tourist objects and attractions. Based on the results of research, the government has a role in the development of sustainable tourism in the city of Kupang. This is in accordance with the Regional Tourism Development Master Plan (RIPPARDA) which has been implemented at the provincial level which has been used as a regional regulation in NTT since 2014-2019, regarding tourism development in the city of Kupang.

So that tourism development in the city of Kupang can be sustainable, it requires the involvement of the private sector in building accessibility in all tourist destinations. Based on the results of the study showed that there is no significant effect of the role of the private sector on sustainable tourism development in the city of Kupang.

The low role of the private sector in sustainable tourism development is caused by several factors, among others: Lack of competent workforce in the field of tourism, so that the private sector uses workers from outside the city of Kupang (Literature, 2018). The City of Kupang has not yet implemented regional regulations governing the private sector in collaborating with communities around tourist destinations. The City Government of Kupang has no regulations, in regulating collaboration between the private sector and the community in tourist destinations, so that the private sector in the City of Kupang, is only looking for profits in investment, and does not prioritize the needs of local communities around the tourist destinations

The role and authority of the private sector (Investors, Universities, NGOs, other tourism actors), namely, promoting tourism objects and driving tourist visits between attractions (Setiawina, et al. 2018). The involvement of the private sector in sustainable tourism development is an obligation, because the private sector is a partner of the government in carrying out tourism development in the field of accessibility development, and as an executor or investor (Wearing in Heny, 2013). The City of Kupang government must issue a regional regulation, which obliges the private sector to make a real contribution through CSA distribution. Based on the results of the FGDs conducted by researchers, it is proven that the private sector engaged in tourism has never distributed CSA to the community around the company (Timex, 2018). The concrete step of the role of the private sector is to set aside CSA to plant mangroves in the mangroef forest, as well as in collaboration with relevant agencies and universities, to conduct counseling on tourism conservation, so as to support sustainable tourism development in Kupang City (Manuk, 2018).

The results showed that social capital had a significant positive effect on sustainable tourism development. Social capital is a major factor in sustainable tourism development. This indicates that social capital has an influence on sustainable tourism development. This is in line with the results of the study of Marriton et al. (2010) which states that in sustainable tourism, social capital influences sustainable tourism development.

Based on research results, social capital has a positive influence on sustainable tourism development, namely, the higher the social capital, the better sustainable tourism development. The results of this study are in line with the results of Hasbullah (2006) which states social capital as an investment in order to get new resources. Fukuyama (1995) states that, by relying on shared norms and values, associations between people will produce trust that ultimately has a large and measurable economic value. Putnam (1993), gives a corroborating statement that good social capital will give birth to a harmonious community life. When juxtaposed with financial capital and human capital, the existence of social capital has a significant difference. Social capital is cumulative and increases by itself (Putnam, 1993).

Research by Mattaritta et al. (2010) states that, in community-based sustainable tourism or tourism as a means to achieve sustainable development goals, social capital must be considered. The key factor found was interaction between community institutions. Social 
capital creates strong intra and extra community relations, open communication, participation, distributive justice and tolerance. Social capital is a foothold in sustainable tourism development, so that norms within the community are not displaced due to the progress of tourism development (Parwata, 2014).

Increasing the capacity of the community to participate in sustainable tourism development as one of the benchmarks of development success and is a reflection that in community development focuses more on the human and community aspects rather than solely on the physical aspects (Sutami, 2009). This is consistent with the results of research and data analysis which states that, community participation has a positive influence on sustainable tourism development. This means that high community participation will support sustainable tourism development in the city of Kupang. Wearing in Heny (2013) said that the community plays an important role in sustainable tourism development because resources and unique traditions are the main drivers of tourism.

The strategy of implementing community participation in sustainable tourism development is by sharing information, formulating goals, setting policies, allocating funding sources, implementing programs and distributing benefits. The community is involved from the planning stage to the implementation of equitable distribution of the results of tourism development, so that tourism development can be felt by the entire community (Wardana, 2017).

Community participation in sustainable tourism refers to local businesses aimed at planning, development and processing related to tourism opportunities (Murphy, 1983) have an impact on providing opportunities for local communities to control and be involved in tourism management and development that have an economic impact on present, and future (Hausler and Garrot, 2001). Community participation in the development of sustainable tourism in the city of Kupang by the government, which is carried out by the private sector, does not answer community needs around tourist destinations.

Based on research and data analysis results, it is stated that community participation significantly mitigates the influence of the role of government, the role of the private sector and social capital on sustainable tourism development in the city of Kupang. Community participation in sustainable tourism development is to provide attractions as tourism products, traditional agricultural land management, traditional ceremonies, handicrafts that can provide an attraction for tourists.

Appropriate cooperation and partnership between the government, the private sector, and the community, to support each other, in order to create sustainable tourism development (Heny, 2013). The results showed that, the variable of community participation, moderating the role of government, the role of the private sector and social capital towards sustainable tourism development in the city of Kupang. Social capital in research serves as a reinforcement of community participation in sustainable tourism development. Social capital also significantly influences the development of sustainable tourism in the city of Kupang.

This finding is in line with the results of Suasapha's (2006) research on the implementation of the concept of community-based tourism on the Kedonganan Coast, showing that social capital owned by one of the supporting factors is the aspirations of the residents of Kedonganan Adat Village. Collectively termed the "sense of community", namely the quality of human relations that causes them to live together in a healthy and sustainable manner that is able to encourage community participation in tourism development (Arief, 2011).

\section{CONCLUSION AND SUGGESTIONS}

It can be concluded that the role of Kupang City Government of East Nusa Tenggara shows a positive influence on community participation. This means that the better the role of government, the higher public participation will be. The role of the private sector in Kupang City shows a positive influence on community participation. This means, the better the role of the private sector, the higher the community participation. Social capital towards community participation. The role of government in the development of sustainable tourism, the higher 
the role of government, the role of sustainable tourism development will be better. The role of the private sector in sustainable tourism development is not significant, this means the lack of the role of the private sector in partnering with the government and the community towards sustainable tourism development in the city of Kupang. Social capital towards sustainable tourism development, the higher the social capital, the more sustainable tourism development will be. Community participation in sustainable tourism, the higher community participation will support the development of sustainable tourism in the city of Kupang. Mediated by community participation, the role of government, private sector and social capital can be said to be significant. This shows that community participation strongly encourages the private sector and government as well as social capital in sustainable tourism development.

It is suggested that community participation is the basis in developing tourist destinations in the city of Kupang. If the government develops tourism in the city of Kupang, it must partner with the community through social roles, cultural roles, economic roles, beliefs, networks and norms that support the tourist attraction in the city of Kupang, which is embodied in Sapta Pesona. The role of the private sector must be further optimized in promoting tourism in the city of Kupang through print or electronic media and organizing tourism events. The private sector partners with communities around tourist destinations in building accessibility and collaborating with the government and related stakeholders, in the field of HR development. Tourism that is developed in the city of Kupang must maintain social capital in the form of cultural values, customs and norms prevailing in society so that local culture is not damaged or dirgerser, due to tourism development. Culture and customs, which must be compounded to be developed, become a tourist attraction. Local community participation in the development of sustainable tourism must be further enhanced by strengthening organizations in the field of tourism, such as forming culinary groups and souvenirs which are the main source of livelihood for the people of Kupang City. Art galleries must also be developed by the government, so that people continue to maintain the culture and customs in the development of sustainable tourism. The role of the private sector must be enhanced, reinforced by the Regional Regulation, which regulates the role of the private sector in the development of sustainable tourism in the city of Kupang.

\section{REFERENCES}

1. Berger. L., 1992, Hotel Crime: Are Yoy as Safe as You Think? Corcporate Travel. November. 26-29.

2. BPS Kota Kupang, 2017, Berita Resmi Statistik, BPS Kota Kupang 2017.

3. Elfianita. E., 2006, Pembangunan Pariwisata Berbasis Community Based Tourism (CBT) di Desa Wisata Limbasari Kecamatan Bobotsari, Kabupaten Purbalingga. Jurnal, UNY.

4. Hair et al. 2010. Multivariate data analysis. Upper Saddle River. Pearson Prentice Hall.

5. Kleden Marianus. 2018 Membangun NTT melalui Sektor Pariwisata, Jurnal Bapeda.

6. Maromon Y Rifat, 2017, Analisis Obyek Wisata Dan Arah Pengembangannya di Kota Kupang Nusa Tenggara Timur (Tesis).

7. Murphy, P.E., 1983, Tourism as Community Industry. Tourism Manag. Vol. 4. 180-193.

8. Nyoman Djinar Setiawina, 2018 Analisis faktor - faktor yang mempengaruhi pembangunan pariwisata di Nusa Panida (penelitian).

9. Parwata, I Putu, 2004, Peran Pemeritah Terhadap Modal Sosial Dalam Pembangunan Pariwisata Berbasis Masyarakat dan Berkelanjutan di Badung Utara (Disertasi).

10. Pemerintah Provinsi NTT 2015, Peraturan Daerah Provinsi NTT No 5 Tahun 2015 Tentang Rencana Pembangunan Kepariwisataan Provinsi NTT Tahun 2015-2025. Kota Kupang Pemprov NTT.

11. Suyana Made, 2006, Pengaruh Perkembangan Pariwisata Terhadap Perekonomian dan perubahan Struktur Ekonomi Serta Kesejahteraan Masyarakat di Propinsi Bali (Disertasi) Universitas Airlangga, Surabaya.

12. Wardana Eka Narinda, 2017 Membangun Pariwista NTT sebagai kekuatan ekonomi daerah. Jurnal Bapeda NTT Volume 5 N0 1 Maret 2017. 